\title{
Geospatial Design of Optimal Water Distribution Network in Ado-Ekiti, Ekiti State, Nigeria
}

\author{
${ }^{1 *}$ UFOEGBUNE, GC; ${ }^{1}$ AYODELE, DO; ${ }^{1}$ ERUOLA, AO; ${ }^{1}$ MAKINDE, AA; ${ }^{1}$ \\ OJEKUNLE, ZO; ${ }^{2}$ ILEVBAOJE, OO
}

\author{
${ }^{I}$ Federal University of Agriculture, Abeokuta, Nigeria \\ ${ }^{2}$ National Centre for Agricultural Mechanization \\ *Correspong Author Email: gidufoes2000@yahoo.co.uk,ufoegbunegc@funaab.edu.ng
}

\begin{abstract}
The supply of water to both rural and urban centres of Nigeria is extremely poor with reference to quantity and access. The study investigated water distribution and supply in Ado-Ekiti metropolis applying a geospatial approach, with a view to generating baseline information to optimize water supply and distribution in the metropolis. Materials used included: a map of Ado-Ekiti with a scale of 1:50000 obtained from the Local Government Office, AdoEkiti water distribution facility map (2000) with a scale of 1:30000 obtained from the Ado-Ekiti State Water Corporation and population estimate of Ado-Ekiti from the Bureau of Statistics. Sets of structured questionnaires were used to get information from the residents and the State's Water Corporation. The study delineated existing water distribution network of the metropolis, provided (i) a map of the service areas, (ii) information on areas with distribution problems and (iii) the per capita demand of the population as inferred from the questionnaires. A lasting solution was also proffered through the design of a water distribution network for the estimated daily water demand for the years 2019 and 2049 irrespective of the variation in water needs of the residents in the area. The Geospatial approach was found to be useful in improving the distribution system through extension of pipelines and identification of various locations for service reservoirs.
\end{abstract}

\section{DOI: https://dx.doi.org/10.4314/jasem.v23i7.3}

Copyright: Copyright (C) 2019 Ufoegbune et al. This is an open access article distributed under the Creative Commons Attribution License (CCL), which permits unrestricted use, distribution, and reproduction in any medium, provided the original work is properly cited.

Dates: Received: 17 May 2019; Revised: 10 June 2019; Accepted 04 July 2019

Keywords: Management, reservoir, distribution problems, served, pipe-borne.

The management of water resources helps protect the world's environment, foster economic growth and sustainable agricultural development, promote democratic participation in governance, and improve health. Assessing a country's overall water supply and demand, through improved ability of governmental and non-governmental organizations to achieve required results, and a coordinated response at local, national, and international levels, effective water resources management is achievable (Oteze, 1981). Alayande (2005) explained that water supply in Nigeria is facing serious challenges and supplyoriented indefinite expansion of water supply infrastructures is stressing the available budgetary allocations to the sector to the limit, with population coverage below satisfactory level. As population grows in urban areas, ensuring a long-term, safe and reliable source of potable water becomes essential. Determining the amount of water needed by residents is an integral component to water management. Even though water is one of the most important natural resource; good for maintenance of life in earth, the way man has been dealing with this resource is far from optimal. Some researchers point out that the instability between supply and demand of water (with supply lower than demand) will be one of the greatest problems faced by humanity in a not so far future (Glenn et al., 2009). According to Glenn et al (2009), it is estimated that in 2025, around 3 billion people will not have access to fresh water. That will represent approximately $60 \%$ of the world population. In spite of the fact that $70 \%$ of the earth is made up of water a lot of people still find it increasingly difficult to get adequate water for consumption, cooking washing, agriculture and manufacturing. In order to achieve this, necessary works such as the water works, water supply systems and waste water disposal systems are put in place.

\section{MATERIALS AND METHODS}

Study area: The study area, Ado-Ekiti is located in the south west of Nigeria and is located in the central part of Ekiti state (Fig. 1a and 1b). It is bounded in the North-West by Irepodun and Ifelodun local government, in the South and East by Ikere and Igboyin respectively. It is located on latitude $7^{\circ} 39^{\prime} 28^{\prime \prime}$ to $7^{\circ} 35^{\prime} 73^{\prime \prime}$ North of the equator and longitude $5^{\circ} 10^{\prime}$ $12^{\prime \prime}$ to $5^{\circ} 19^{\prime} 20^{\prime \prime}$ East of the Greenwich meridian. Following the creation of Ekiti state on October 1, 1996, Ado-Ekiti became a capital city. The city lies 
entirely within the Pre-Cambrian Basement Complex Rock group which underlies most south western part of Nigeria. Due to its peculiar gneisses formation with small aquifers and relatively shallow overburden, Ado-Ekiti is poor in groundwater potentials (Fadipe and Adeduro, 1993; Ebisemiju, 1993). These peculiarities result into low yield situation of boreholes in this city while most wells often dry up during dry season. Ado-Ekiti experiences a tropical climate with distinct wet and dry seasons. Just like most of the south-western settlements in Nigeria, it has two rainfall regimes. The annual rainfall is about $1400 \mathrm{~mm}$ and the mean annual temperature is about $27^{\circ} \mathrm{C}$. These seasons are associated with the prevalence of maritime south westerly monsoon winds from the Atlantic Ocean and the dry continental north easterly harmattan winds from the Sahara Desert.
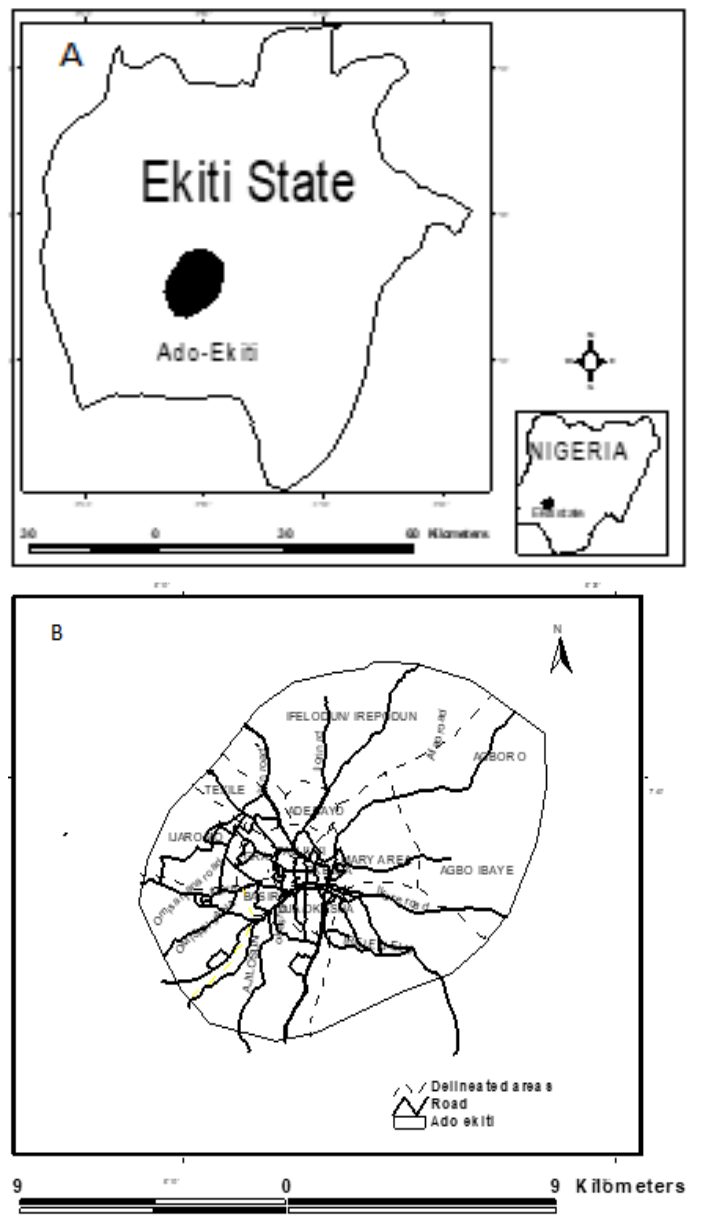

Fig 1: Ado-Ekiti Metropolis ( $\mathrm{A}=$ Ekiti state showing location of Ado-Ekiti and $\mathrm{B}=$ Ado-Ekiti)

The city therefore enjoys water surplus between May and October with substantial water deficit between November and April when all stream channels are completely dry while the main rivers are reduced to a chain of pools (Ebisemiju, 1993). The city is known for the production of yam, cocoa, cassava, rice and oranges amongst other cash crops. The heavy rainfall favors the climate condition for the growth of thick and luxuriant vegetation of trees such as Mahogany, Iroko and Obeche. Ado-Ekiti is mainly an upland area that rises at about 250 metres above sea level. It is on an altitude of about 200 metres above sea level in the South-Eastern part of the Ureje stream and 500 metres above sea level in the North-East. The landscape is also characterized by rounded isle bergs and sided volcanic hills among which is the popular Olota. Most part of this area is underlain by the ancient crystalline igneous and metamorphic rocks generally referred to as Pre-Cambrian Basement Complex (Source Ekiti State Surveys, Ado- Ekiti Nigeria 2000).

The provision of water in Ekiti State has been the responsibilities of three major stakeholders: the government (via the Ekiti State Water Corporation), the donor agencies and the people in their respective communities. The various sources available to the inhabitants of the state ranges from brooks, wells, springs, ponds, rivers, bore holes, rain water to pipe borne water. The Ekiti State Water Corporation achieves this through the supply of water from the water works water supply scheme. This scheme was commissioned in 1961 and had Ado-Ekiti and ikere as its coverage area. It has the Ureje dam as its source and had a design capacity of 204,700,000 litres. At, inception, it was designed to supply the people Ikere and Ado-Ekiti water. It has a distribution main of $12 \mathrm{~km}$ of $200 \mathrm{~mm}$ diameter ( 8 inches) to Ikere and a rising main of $4 \mathrm{~km}$ of $200 \mathrm{~mm}$ ( 8 inches) diameter to GRA (Government residential area). It barely serves the people of Ikere as a result of distribution pipes vandalisation by road construction. A new treatment plant was constructed in the year 2008 at the water works scheme to help boost the quantity of water supplied, yet water supply has not been adequate. There are six reservoirs serving the city of Ado-Ekiti as shown in Table 1.

Materials: The data collected were primary and secondary data. Primary data was collected by administration of two sets of structured questionnaires. For the distribution of questionnaires, the study area was divided into five zones (North-east, South-west and North-west, South-east and Central region of AdoEkiti). Each zone was allocated 240 questionnaires bringing the total number of questionnaires to be administered to 1200 . A questionnaire was also sent to the Ekiti State Water Corporation in order to get information from other stakeholders apart from the consumers. The Geographic Information System software was used in delineating the existing roads and water distribution networks in the city. The secondary data used include, a map of Ado-Ekiti with a scale of

UFOEGBUNE, GC; AYODELE, DO; ERUOLA, AO; MAKINDE, AA; OJEKUNLE, ZO; ILEVBAOJE, OO 
1:50,000 obtained from the Local Government Office, water distribution facility map of Ado-Ekiti obtained from the Ekiti State Water Corporation (2000) with a scale of 1:30,000 and Ado-Ekiti population estimate obtained from the Bureau Office of Statistics, Ekiti
State. Arcview 3.3a was used to perform the spatial analysis.

Table 1: Reservoirs in Ado-Ekiti

\begin{tabular}{llll}
\hline & & Design & $\begin{array}{l}\text { Dunction } \\
\text { capacity }\left(\mathbf{m}^{\mathbf{3}}\right)\end{array}$ \\
\hline Ureje dam (old treatment plant) & Concrete reservoir (clear well) & Headworks & 5000 \\
Ureje dam (new treatment plant) & Stainless steel reservoir (clear well) & Headworks & 5000 \\
GRA & Concrete Reservoir & Storage and Distribution & 1000 \\
Fajuyi & Concrete Reservoir & Booster station & 1300 \\
Okeila & Concrete Reservoir & Storage and Distribution & 1000 \\
Mary hill & Concrete Reservoir & Storage and Distribution & 500 \\
\hline
\end{tabular}

\section{Assumptions:}

$\mathrm{P}_{\mathrm{n}}=\mathrm{P}_{\mathrm{o}}(1+\mathrm{r} / 100)^{\mathrm{n}} \quad P n=\left(1+\frac{r}{100}\right) n$

Where $\mathrm{P}_{\mathrm{n}}=$ Projected population, $\mathrm{P}_{\mathrm{o}}=$ Initial population figure, $\mathrm{r}=$ Growth rate $=6.48 \%$ (Source: NPC, 2006).

Per capita per day consumption $=80$ litres $($ World Bank).

The average daily demand of the population per day $=$ population $\mathrm{x}$ per capita per day consumption.

Methodology: The analogue water utility sketch map was scanned, geo-referenced, and digitized. This was super imposed on the derived map of the metropolis and the existing water distribution network of the city was delineated. The software was queried to find new areas for siting reservoirs with the help of the digital terrain model of the metropolis. Possible reservoir locations were suggested using queries module. A proximity analysis to show areas to be included in design of the utility network and those left out was first carried out. This having been carried out, the optimal location of reservoirs and pumping station was determined using the overlay functionality to identify the best positions to locate new reservoirs bearing in mind the criteria for siting a reservoir. Areas suitable for siting reservoirs were those with an average elevation of above 460 metres depending on the location. This is because reservoirs must be located at the highest possible elevation in order to maximize gravity flow of water. It also reduces additional costs usually incurred in constructing booster stations. Another criterion that was considered was the distance from inhabited areas. For the purpose of this study, a buffer of 750 metres was to be created from all inhabited areas within the metropolis, major roads and streams. A new distribution map which covers the whole of Ado-Ekiti was drawn using the software after calculations on the expected water demand and reservoir capacity had been done. The projection was made on the current existing capacity which is 204, 700, $001 /$ day. It was estimated that a total of three reservoirs will supplement the needs of the people in the year 2019 and two more in the year 2049 with a capacity of $1000 \mathrm{~m}^{3}$ each provide that treated water is pumped into them regularly as and when needed. Therefore, new reservoirs were located on the map and new pipelines were drawn in the inhabited areas.

Statistical Analysis: Statistical analysis was carried out on the questionnaires using descriptive analysis to determine the objectives of the research.

\section{RESULTS AND DISCUSSION}

The figure 2 below depicted Ado-Ekiti showing the existing facilities of Ekiti state water corporation. The facilities of the Corporation include the pipelines and reservoirs in Table 1 . The figure showed that only the central part of the metropolis and the extreme southern ends of the city are served. This cannot possibly cater for the water requirements of the city especially as population keeps expanding. Thus the city is in need of additional water distribution facilities.

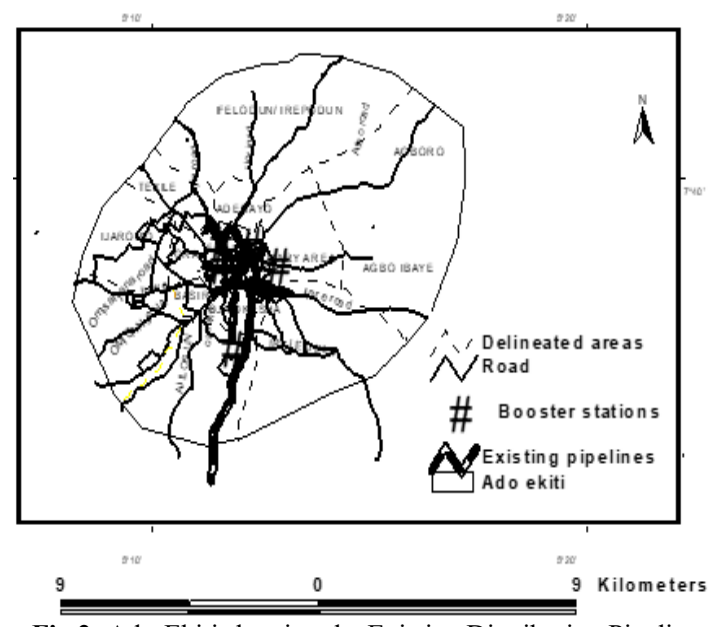

Fig 2: Ado-Ekiti showing the Existing Distribution Pipeline

The next figure below showed that the Central region which is served by the Corporation has the highest occurrence of distribution problems. Other areas experience little or no problems. 


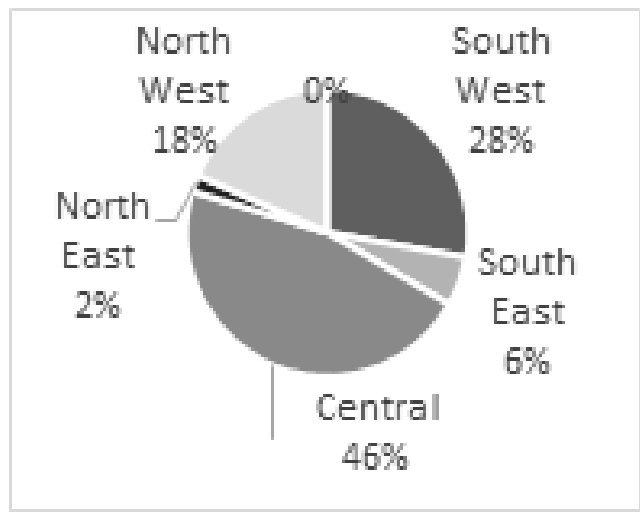

Fig 3: Areas with Distribution Problems

The figure below (figure 4) showed that the average estimated per capita demand for the city is 45-90 litres of water which is synonymous to the World Bank Standard of 80 litres per day.

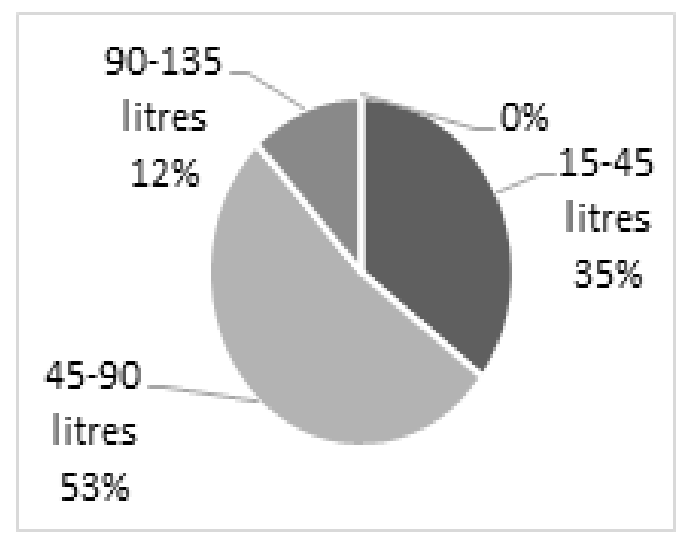

Fig 4: Per Capita Demand of Water for Ado-Ekiti Metropolis.

The degree of service of water supply to the Metropolis was given in the figure 5 while the estimated daily water demand for the population was also depicted with table 3 . The figure 5 showed that most of the outlying areas are unserved except for Ajelosun while the inner metropolis was relatively well served. The GIS was queried to locate possible areas for siting the reservoirs. These areas were required to be above 460 metres. It is from this query that the possible sites were obtained. New pipelines were connected to the reservoirs following the existing roads in inhabited areas. The study found that the water distribution network of the metropolis was skewed to the centre. Only areas in this part of the city are served therefore the need to expand and improve on the water distribution and supply in the city. This corresponds with Bankole (2010) who drew a general inference that there are problems as regards water supply in the three senatorial districts of the state.

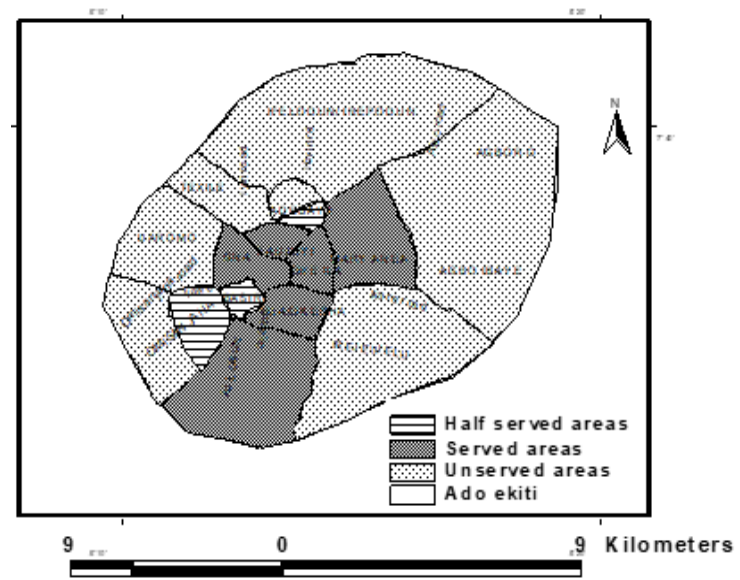

Fig 5: Served and underserved areas.

\begin{tabular}{lll}
\multicolumn{3}{c}{ Table 3: Estimated daily water demand for the population } \\
\hline Year & $\begin{array}{l}\text { Population Estimate } \\
\text { (People) }\end{array}$ & $\begin{array}{l}\text { Average Daily Demand. } \\
\text { (litres per day) }\end{array}$ \\
\hline 2019 & 665735 & 53258831 \\
2049 & 4378677 & 350294166 \\
\hline
\end{tabular}

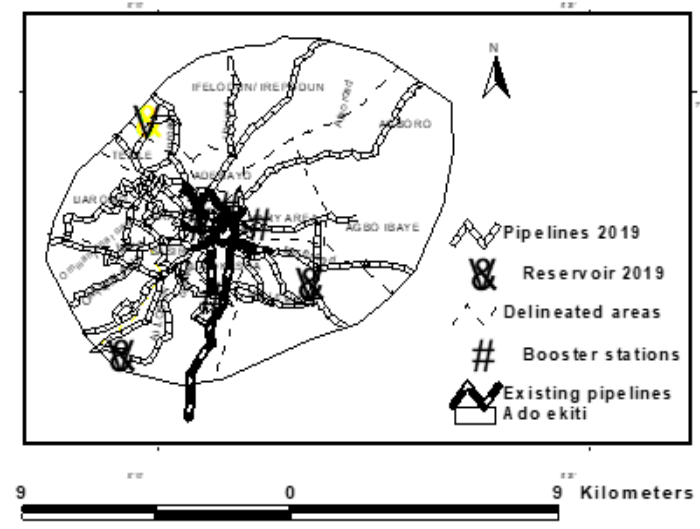

Fig 6: A proposed Map of water distribution in the year 2019.

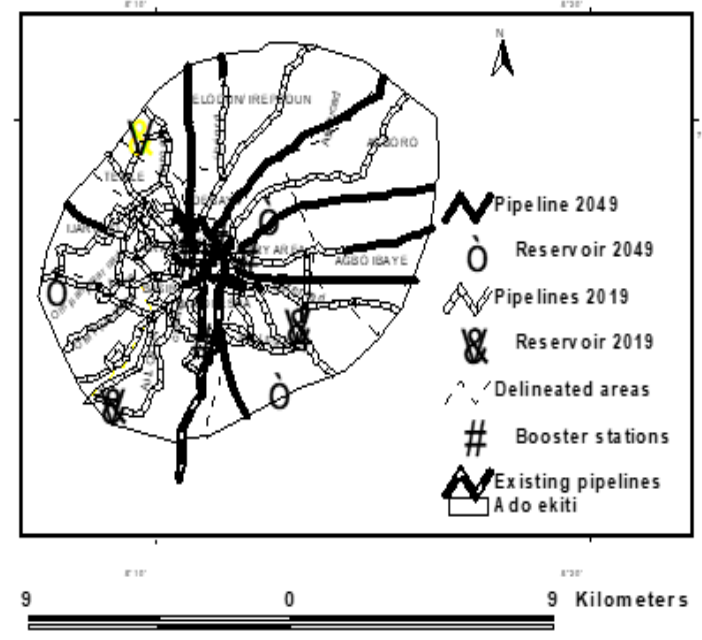

Fig 7: A proposed Map of Water Distribution in 2049. 
The central region of the city which is the most served has more distribution problems than the other less served parts of the city. It is important to determine distribution problems and their causes because there is extensive evidence that inadequate management of drinking-water distribution systems has led to outbreaks of illness in both developed and developing countries. Between 1981 and 2010 in the United States of America (USA), 57 outbreaks were associated with distribution system faults, leading to 9000 cases of illness ( St Louis, 1988; Levine et al., 1990; Herwaldt et al., 1991; Moore et al., 1993; Kramer et al., 1996; Levy et al., 1998; Blackburn et al., 2004; 2006; Yoder et al., 2008; Brunkard et al., 2011; Hilborn et al., 2013). In recent years, much attention has been paid to preventing contamination of water sources as a first step, followed by selecting reliable operating treatment processes. Evidence from the USA shows that this has been successful in reducing waterborne outbreaks associated with inadequate treatment, particularly of surface water supplies (Craun et al., 2006). This should be implemented in the study area as the study showed that showed that not all the population gets water from the public water source. In addition, stresses caused by rapid urbanization increase population growth and ageing infrastructure could further exacerbate problems with distribution systems as is evident in the increase of the per capita demand of water in successive years of 2019 and 2049. The estimated daily water demand for the population show the quantity of water expected to be supplied in the year 2019 and 2049 which is greater than the current daily supply of 7,396,00 litres per day. The distribution network deigned is expected to augment the shortfall in the year 2019 and 2049 was projected. This covers the entire city and serves the areas in need of additional facilities.

Conclusion: The map of distribution network designed for the projected water demand in the year 2018 and 2048 should be used by policy makers to cater for the water needs of the people. This will improve the water supply and distribution in the metropolis. Furthermore, the use of GIS should be encouraged to locate areas of the metropolis in need of additional facilities as the metropolis expands.

\section{REFERENCES}

Alayande, AW (2005). 'Water Demand Management', Delivered at the Urban Water Supply Facilities Maintenance Courses held at National Resources Institute, Kaduna, November $7^{\text {th }}-8^{\text {th }} 2005$.

Ayoade, JO and Oyebade, BL (1978). 'A Geography of Nigerian Development', Heinemann Educational books Nigeria Ltd, Ibadan.
Bankole, BO (2010). The Geographical Distribution of Water Supply in Ekiti State, African Research Review, 4:2, ISSN 20700083. Available at: dx.doi.org/10.4314/affrev.v4i2.58291.

Brunkard, JM; Ailes, E; Roberts, VA; Hill, V; Hilborn, ED and Craun, GF (2011). 'Surveillance for waterborne-disease outbreaks associated with drinking water - United States, 2007-2008', MMWR CDC Surveill Summ., 60(12): 38-74.

Blackburn, BG; Craun, GF; Yoder, JS; Hill, VH; Calderon, RL and Chen, N (2004). 'Surveillance for waterborne-disease outbreaks associated with drinking water - United States 2001-2002', MMWR CDC Surveill Summ., 53(8): 23-45.

Chaudhery, K (2005). 'Wastewater Infrastructure Planning Using GIS, Proceedings of MAP India 2005 Conference', India.

Craun, MF; Craun, GF; Calderon, RL and Beach, ML (2006).' Waterborne outbreaks reported in the United States', J Water Health, 4:19-30.

Ebisemeju, FS (1993). 'Hydrology and Surface Water Resources Ado Ekiti Region', $1^{\text {st }}$ Edition, AdoEkiti Nigeria, Alpha Prints, 41-45, ISBN: 978028-466-4.

Glenn, JC; Gordon, TJ and Florescu. E (2009). 'The Millenium Project Washington DC 2014', ISBN: 978-0-9887639-1-8.

Herwaldt, BL; Craun, GF; Stokes, SL and Juranek, DD (1991). 'Waterborne-disease outbreaks 19891990’, MMWR CDC Surveill Summ., 40(3):1-22.

Hilborn, ED; Wade, TJ; Hicks, L; Garrison, L Carpenter, J and Adam, E (2013). 'Surveillance for waterborne disease outbreaks associated with drinking water and other non-recreational waterUnited States 2009-2010', Morb Mortal Wkly Rep, 62(35): 714-20.

Hunter, P.R., Chalmers, R.M., Hughes, S., and Syed, Q. (2005). 'Self-reported diarrhea in a control group: a strong association with reporting of lowpressure events in tap water', Clin Infect Dis., vol.40, pp. 4-32.

Kramer, MH; Herwaldt, BL; Calderon, RL and Juranek, DD (1996). 'Surveillance for waterborne-disease outbreaks - United States 1993-1994', MMWR CDC Surveill Summ., 45(1):1-33. 
Levine, WC; Stephenson, WT and Craun, GF (1990). 'Waterborne disease outbreaks 1986-1988', MMWR CDC Surveill Summ., 39(1):1-9.

Moore, AC Herwaldt BL, Craun GF, Calderon RL, Highsmith AK, Juranek DD, (1993), 'Surveillance for waterborne-disease outbreaks United States 1991-1992', MMWR CDC Surveill Summ., 42(5):1-22.

National Population Commission, (2006). 'Population Commission', Abuja.

Oteze GE (1981). 'Water Resources in Nigeria Environment', Spriger Bertlin Heidel berg, 3:177-184.

Oyebande, L (2005). 'Water Resources in Adalemo', I.A. and Baba, J.M. (editors) Nigeria: Giant in the Tropics, A Compendium., Gabumo Publishing Co. LTD.

St Louis, ME (1988) 'Water-related disease outbreaks 1985’, MMWR CDC Surveill Summ., 37(2), 1524

Ufoegbune, GC; Atanley, PA; Eruola, AO; Makinde, AA and Ojekunle, ZO (2016). 'Geographical Information System (GIS) Application for Planning and Improvement of Public Water Supply in Ota, Ogun State, Nigeria', J. Appl. Sci. Environ. Manage. 20 (4):1105- 1111
Ufoegbune, GC; Oparinde, OC and Eruola, AO (2011). 'Municipal water supply Planning in Oyo metropolis, Oyo State, South Western Nigeria', $J$. Geog. Reg. Plan. 4 (7): 392-400

Ufoegbune, GC; Oguntoke, O; Adeofun, $\mathrm{CO}$ and Salako, A (2008). 'Remote Sensing Techniques applied to Time Related Changes in the Land-use of Abeokuta and its Environs, South-Western Nigeria', Asset Series A, 8(1):98-108

Ufoegbune, GC: Ladipo-Ajayi, O; Oyedepo, J and Eruola, AO (2009). 'GIS Application to Municipal Water Supply Planning in Abeokuta Metropolis, Southwestern Nigeria', J. Meteor. Climate Sci. 7:23-27.

Van, L J; Blokker, EJM; Medema, G; Hambsch, B; Pitchers, R and Stanfield, G (2006). 'MicroRisk: contamination during distribution Performed as part of the Micro Risk project that is cofounded by the European Commission under the Fifth Framework Programme', Theme 4:"Energy, environment and sustainable development". Available at: http://www.microrisk.com/uploads/microrisk_dis tribution_assessment.pdf, accessed 6 May $20 \overline{1} 8$.

Yoder, J; Roberts, V; Craun, GF; Hill, V; Hicks, L and Alexander, NT (2008). 'Surveillance for waterbornedisease outbreaks associated with drinking water and water not intended for drinking - United States 2005-2006', MMWR CDC Surveill Summ., 57(9): 39-69 